\title{
A DEVASTATING PLINIAN ERUPTION AT TUNGURAHUA VOLCANO REVEALS FORMATIVE OCCUPATION AT 1100 CAL BC IN CENTRAL ECUADOR
}

\author{
J-L Le Pennec ${ }^{1,2,3,4} \bullet$ G de Saulieu ${ }^{5}$ P Samaniego ${ }^{1,2,3} \bullet$ D Jaya $^{6} \bullet$ L Gailler $^{1,2,3}$
}

ABSTRACT. Based on archaeological and radiometric constraints, previous studies have divided pre-Columbian times of Ecuador into a succession of cultural periods. The Paleoindian and Preceramic periods encompass the time from the first Amerindian occupation to about 4000 BC. The Formative period extends from 4000 to 300 BC, while the Regional Development ( 300 BC to $\sim A D ~ 700$ ) and Integration periods predate the Columbian period, which starts in AD 1533 in Ecuador. The Formative cultural period is poorly known from earlier studies. Here, we bring the first documentation of Formative age occupation around Tungurahua Volcano, $120 \mathrm{~km} \mathrm{SW}$ of Quito, and show that local settlements were devastated by a violent eruption around $1100 \mathrm{cal} \mathrm{BC}$. Recent volcanological works combining lithostratigraphic, petrologic, and geochronologic analyses reveal that the steep-sloped Tungurahua edifice suffered a major Late Holocene flank failure. We show that the failure event resulted from a major explosive eruption triggered by massive magma intrusion inside the volcano. Decompression of the magma due to a flank collapse resulted in a violent, high-velocity directed blast explosion, which deposited charcoaland sherd-rich ash layers upon and near the volcano. Our ${ }^{14} \mathrm{C}$ results range from $2225 \pm 30$ to $5195 \pm 45 \mathrm{BP}$, but most cluster between $2640 \pm 45$ and $3195 \pm 45$ BP. A calibration analysis indicates that the event took place at 1100 cal BC, in the Formative period. We gathered 38 pottery sherds from 3 localities. The sherds show a diversity of size, shape, color, and ornamentation. Examination of pastes, surface finish, and firing indicates that our material shares many common features from site to site. The material from Tungurahua shares affinities with the Cotocollao tradition, which developed in the Quito region between 1500 and $500 \mathrm{BC}$, and with the Machalilla tradition (coastal region of Ecuador), with the occurrence of carinated bowls with punctuate decorations at 1500-1000 BC. Our study reveals that the 1100 cal BC Plinian eruption of Tungurahua Volcano is among the oldest known volcanic disasters in the Andes.

\section{INTRODUCTION}

Based on archaeological and radiometric constraints, previous studies have divided pre-Columbian times of Ecuador into a succession of cultural periods. The Paleoindian and Preceramic periods include the time from the first Amerindian occupations up to about 4000 BC. The subsequent Formative period extends from $\sim 4000$ to $~ 300 \mathrm{BC}$, while the later Regional Development ( 300 BC to $\sim A D$ 700) and Integration periods predate the Columbian period, which starts in AD 1533 in Ecuador. Archaeological remains collected in Cotocollao, a site near Quito city (Figure 1), characterize the Formative cultural period of northern Ecuador. Rare remains with Cotocollao affinities have been described northwest of Pichincha Province (Lippi 1998), and in Cotopaxi and Chimborazo provinces (private collections and collection of the Banco Central of Riobamba). However, the Formative period is still very poorly known from earlier studies.

Explosive volcanic activity has been a frequent phenomenon in the Ecuadorian ranges (Figure 1) and repeatedly affected pre-Columbian communities of the inter-Andean corridor (e.g. Athens 1999; Guillaume-Gentil 2008; Hall and Mothes 2008; Rostain 2012). For example, the powerful Quilotoa eruption around 800 BP translated into severe regional destructions and seemingly triggered massive migration of inhabitants in the Integration period (Hall and Mothes 2008). Other dev-

\footnotetext{
${ }^{1}$ Laboratoire Magmas et Volcans, Clermont Université, Université Blaise Pascal, BP 10448, 63000 Clermont-Ferrand, France.

${ }^{2}$ CNRS, UMR 6524, Laboratoire Magmas et Volcans, 5 rue Kessler, 63038 Clermont-Ferrand Cedex, France.

${ }^{3}$ IRD, R 163, Laboratoire Magmas et Volcans, 5 rue Kessler, 63038 Clermont-Ferrand Cedex, France.

${ }^{4}$ Corresponding author. Email: jeanluc.lepennec@ird.fr.

${ }^{5}$ IRD, UMR 208 “Paloc,” IRD-MNHN, France.

${ }_{6}^{6}$ Instituto Geofisico, Instituto Geofísico, Escuela Politécnica Nacional, Ap. 17-01-2759, Quito, Ecuador. Now at Caminosca LTD, Quito, Ecuador.
} 


\section{J-L Le Pennec et al.}

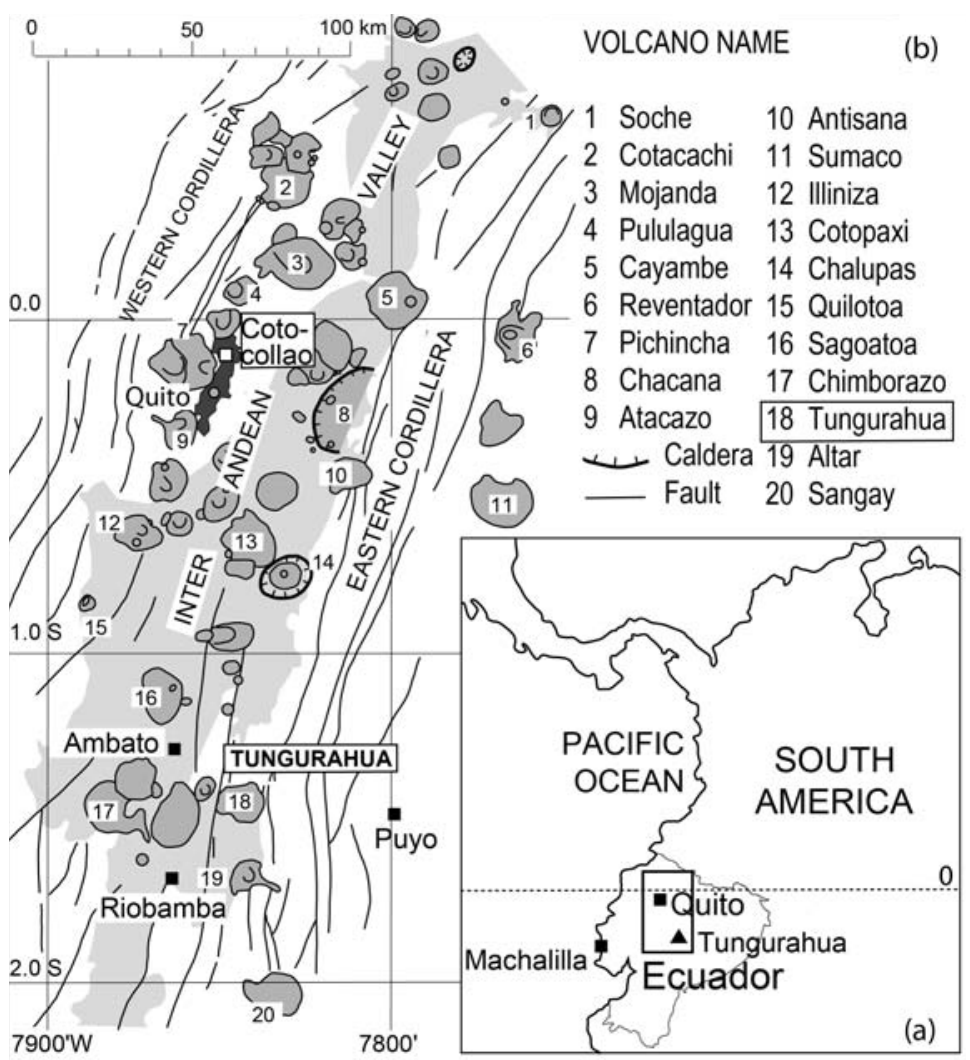

Figure 1 Map of Tungurahua Volcano within the Ecuadorian volcanic arc. (a) Inset shows the location of Tungurahua Volcano (triangle), Quito city, and Machalilla on the Ecuadorian coast. (b) The main figure displays the volcanoes of the Ecuadorian Sierras with the inter-Andean valley depicted in light gray. Quito city is delineated as a dark gray area and Cotocollao locality is identified as a white square in the northern part of Quito. Other cities cited in the text (Ambato, Riobamba, and Puyo) are also shown.

astating eruptions likely occurred in pre-Columbian times, but detailed evidence has been lacking. Here, we bring the first documentation of human occupation of Formative affinity around Tungurahua Volcano, $120 \mathrm{~km}$ southwest of Quito (Figure 1), and show that local settlements were devastated by a violent explosive eruption at $\sim 1100$ cal BC. We examine the volcanological context, which enables identification of a distinctive tephra layer in the volcano's history, present new radiocarbon age determinations, and describe the associated archaeological material. The ${ }^{14} \mathrm{C}$ data were obtained at the Center for Isotope Research at Groningen University, the Netherlands (GrA = AMS; $\mathrm{GrN}=$ conventional).

\section{TUNGURAHUA VOLCANO AND THE 1100 CAL BC ERUPTION}

\section{Evidence for a Sector Collapse Associated with a Plinian Eruption}

Tungurahua volcano sits in the Eastern Cordillera of central Ecuador. The cone-shaped edifice culminates at $5023 \mathrm{~m}$ above sea level, and its northern base occurs in the Pastaza River Valley, a deep and wide canyon that connects the inter-Andean valley of the Ecuadorian Sierras to the Amazonian lowlands (Figure 1). The Holocene eruptive activity of Tungurahua has received ample attention 


\section{Plinian Eruption at Tungurahua Reveals Formative Occupation}

since its hazardous reactivation in 1999. Recent investigations, combining lithostratigraphic, petrologic, and geochronologic analyses, reveal that the steep-sloped volcano suffered a major flank failure collapse in the Late Holocene, as evidenced by typical debris avalanche breccias overlying a lahar deposit dated around 3 ka BP (Hall et al. 1999; Le Pennec et al. 2008; Samaniego et al. 2011). This article shows that the debris avalanche and lahar deposits result from a major flank failure event triggered by massive magma intrusion inside the volcano.

A section near the cemetery of Baños, a touristic town near the northern base of the volcano (Figure 2), exposes an eye-catching lapilli layer $\sim 80 \mathrm{~cm}$ in thickness. The tephra deposit occurs as 2 well-sorted, faintly stratified layers of coarse-grained lapilli separated by a thinner, 3-cm-thick finegrained lapilli and coarse-grained ash beds (Figure 3). The basal 53-cm-thick lapilli layer consists of whitish pumice clasts near the base, grading upward to brownish dark-toned strata of scoria fragments. The upper 23-cm-thick lapilli layer is a succession of scoria beds, with large highly porous clasts at the top. Apart from the juvenile material (i.e. pumice and scoria belonging to the initially hot magma of the eruption), the deposit contains abundant elements of old volcanic material, including dark lava clasts, reddish scoriaceous fragments, and distinctive hydrothermally altered yellowish, clay-rich fragments. The lapilli strata rest directly upon a massive 1-m thick, fine-grained deposit of volcanic ash. Rare subangular pumice and scoria lapilli are present and fragments of ceramic sherds occur in the ashy matrix. In addition, small charcoal pieces scattered in the ash reveal that this massive layer was emplaced at high temperature, most likely as a hot pyroclastic density current. A ${ }^{14} \mathrm{C}$ determination yielded an age of $3195 \pm 45 \mathrm{BP}\left(\mathrm{GrA}-24128\right.$, all ${ }^{14} \mathrm{C}$ results are reported in Table 1). The features (e.g. thickness, componentry, and chemical composition of the juvenile clasts; see below) of the upper stratified lapilli and lower massive ash deposits are uncommon in the recent Holocene tephra record of Tungurahua. Hence, these layers may serve as a valuable stratigraphic key horizon upon and around Tungurahua Volcano.

Higher on the edifice, similar deposits are exposed near the touristic viewpoint of the Runtún Plateau (Figure 2). There, the main lapilli deposit occurs as a conspicuous 40- to 50-cm-thick bed above the coffee-toned ash layer, and both host many sherds of different size and shape (see below). A ${ }^{14} \mathrm{C}$ age of $5195 \pm 45$ BP (GrA-34156, Table 1) has been obtained on small charcoals, while recent redating of the same horizon beneath the main lapilli deposit yields an age of $2225 \pm 35$ BP (GrA-55345, Table 1). Near Huayrapata, a hill located northwest of the volcano (Figures 2 and 3), a road cut exposes similar but thinner deposits. The lapilli layer ( $\sim 50 \mathrm{~cm}$ thick) is composed of identical tephra elements and the lower ash-rich beds host carbonized twigs, which yield a ${ }^{14} \mathrm{C}$ age of $2640 \pm 45 \mathrm{BP}$ (GrN-27847). North of Chazo village, near the road to Sahuazo community (Figures 2 and 3), the succession consists of a 27-cm-thick lapilli layer (with $3 \mathrm{~cm}$ for the ash bed between the 2 main lapilli strata) overlying more than $3 \mathrm{~m}$ of massive grayish ash. The latter deposit hosts ceramic fragments as well as small charcoal pieces, which give AMS ages of $2915 \pm 40$ BP (GrA-23911) and $2845 \pm 40$ BP (GrA-34159, Table 1). In road cuts between La Providencia and Cahuaji, southwest of the volcano (Figure 2), extended tephra successions of recent eruptive Tungurahua activity are exposed, and the distinctive volcanic layers described above are identified at the base of the young (<3 ka BP) Tungurahua succession (Hall et al. 1999; Le Pennec et al. 2008). Small charcoal fragments collected in the lower ash-rich deposit yield a ${ }^{14} \mathrm{C}$ age of $3045 \pm 45 \mathrm{BP}$ (GrA-33878). In Quebrada Mandur, a ravine located on the northwestern flank of the volcano (Figure 2), the layers rest directly on top of a dacitic breccia belonging to the debris avalanche of the sector collapse. Here, small charcoals are dated at $2255 \pm 45 \mathrm{BP}$ (GrA-31243).

The age of the debris avalanche event was previously inferred from a ${ }^{14} \mathrm{C}$ determination of $2955 \pm$ $90 \mathrm{BP}$ obtained on non-carbonized logs collected in a cliff near Cotalo village, in a debris flow 


\section{J-L Le Pennec et al.}

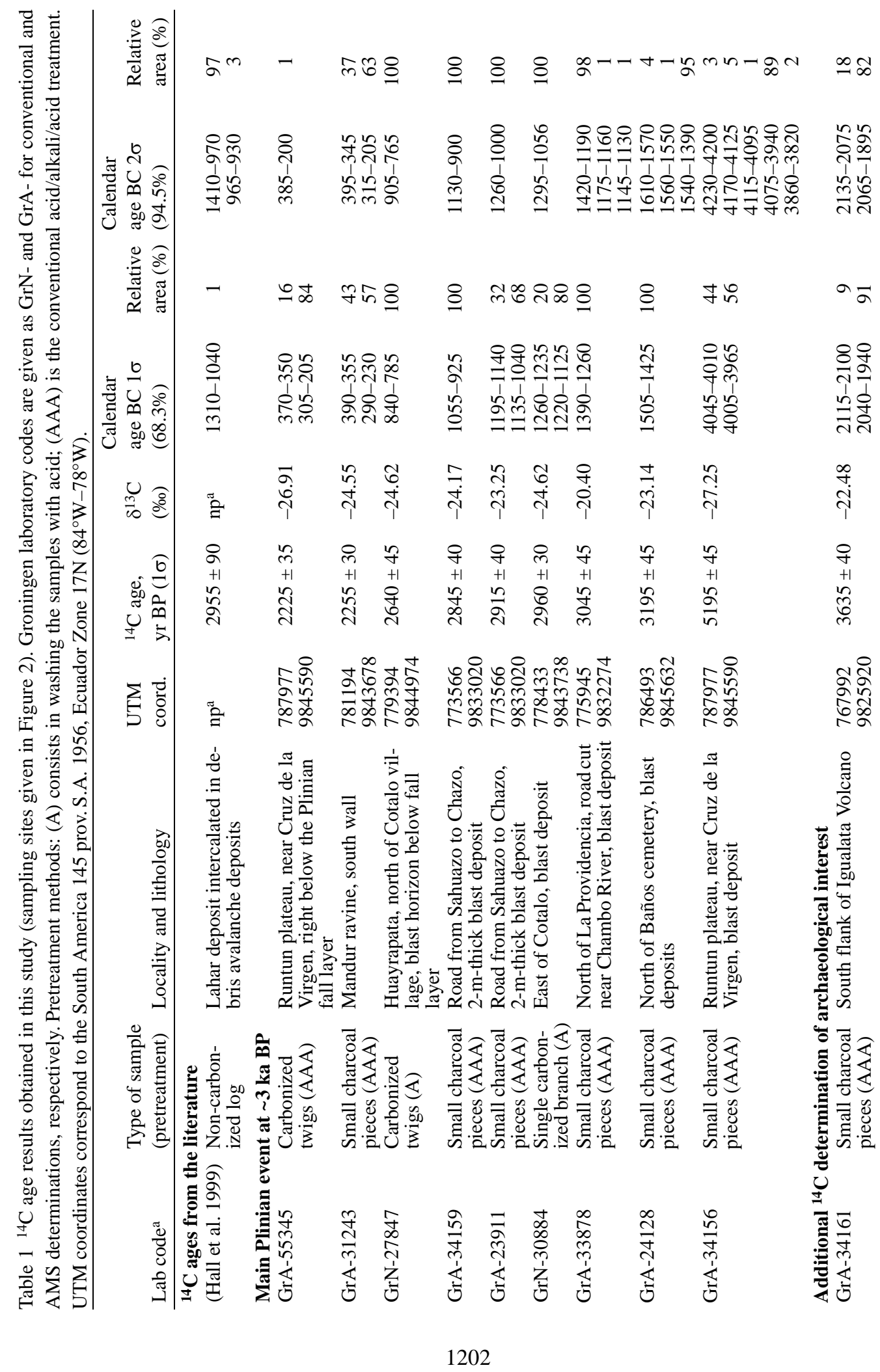


Plinian Eruption at Tungurahua Reveals Formative Occupation

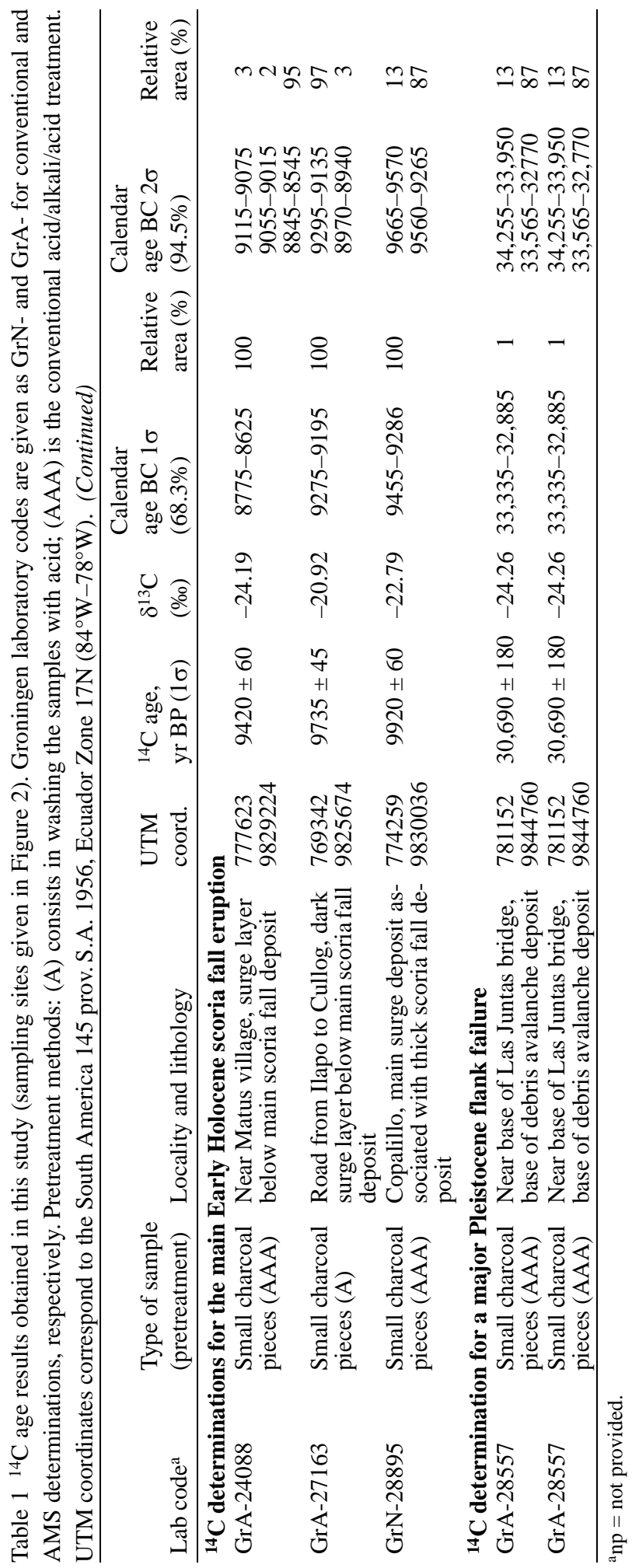




\section{J-L Le Pennec et al.}

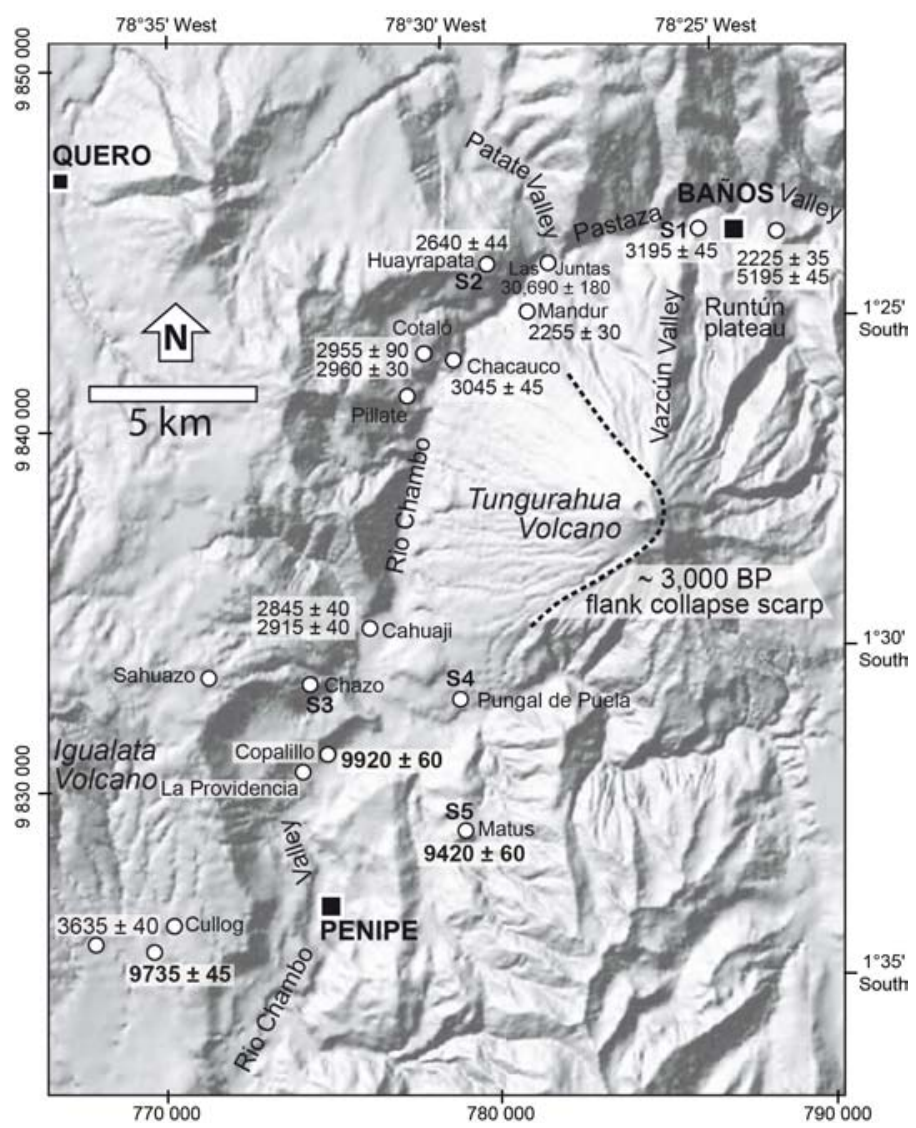

Figure 2 Shaded relief map of Tungurahua Volcano, with locality names given in the text. ${ }^{14} \mathrm{C}$ sampling sites are indicated with laboratory codes as in Table $1 .{ }^{14} \mathrm{C}$ determinations in regular text refer to the $\sim 3 \mathrm{ka}$ BP deposits, while those in bold text refer to the major scoria fall layer emplaced at $\sim 9.7 \mathrm{ka}$ BP. The dashed line on Tungurahua Volcano delineates the scarp of the avalanche caldera amphitheater left by the $\sim 3 \mathrm{ka}$ BP flank failure event.

(lahar) deposit interbedded between 2 debris avalanche breccias (Hall et al. 1999). However, our reexamination of the deposit strongly suggests that the dated lahar correlates to our massive ash deposit of Baños cemetery, and a new ${ }^{14} \mathrm{C}$ analysis of fully carbonized twigs yields an age of $2960 \pm$ 30 BP (GrN-30884). The avalanche deposit above this layer should be the most recent flank collapse associated with the $\sim 3 \mathrm{ka}$ BP event, and we infer that the lower debris avalanche breccia belongs to an older flank failure event. Our first age determinations of a thick conspicuous scoria fall layer exposed in the southwestern area of the volcano corroborate this inference. ${ }^{14} \mathrm{C}$ dating of small charcoal pieces in ashy volcanic surge deposits associated with this scoria layer near Matus (Figures 2 and 3, Table 1) yields an age of $9420 \pm 30 \mathrm{BP}$ (GrA-24088). The same layer crops out in many places to the southwest of the volcano and AMS determinations of small carbonized vegetal debris gave ${ }^{14} \mathrm{C}$ ages of $9920 \pm 60 \mathrm{BP}$ (GrA-33878) at Copalillo, and $9735 \pm 45 \mathrm{BP}$ (GrA-27163) on the southern flank of Igualata Volcano west of Cullog (Figure 2, Table 1). We observed in recent road cuts of La Providencia area that this key scoria layer rests unconformably upon the eroded top of a major debris avalanche deposit extensively exposed in the area of Chazo, La Providencia, and Penipe. It implies that the avalanche deposit is significantly older than the overlying $~ 9.7 \mathrm{ka}$ BP sco- 


\section{Plinian Eruption at Tungurahua Reveals Formative Occupation}

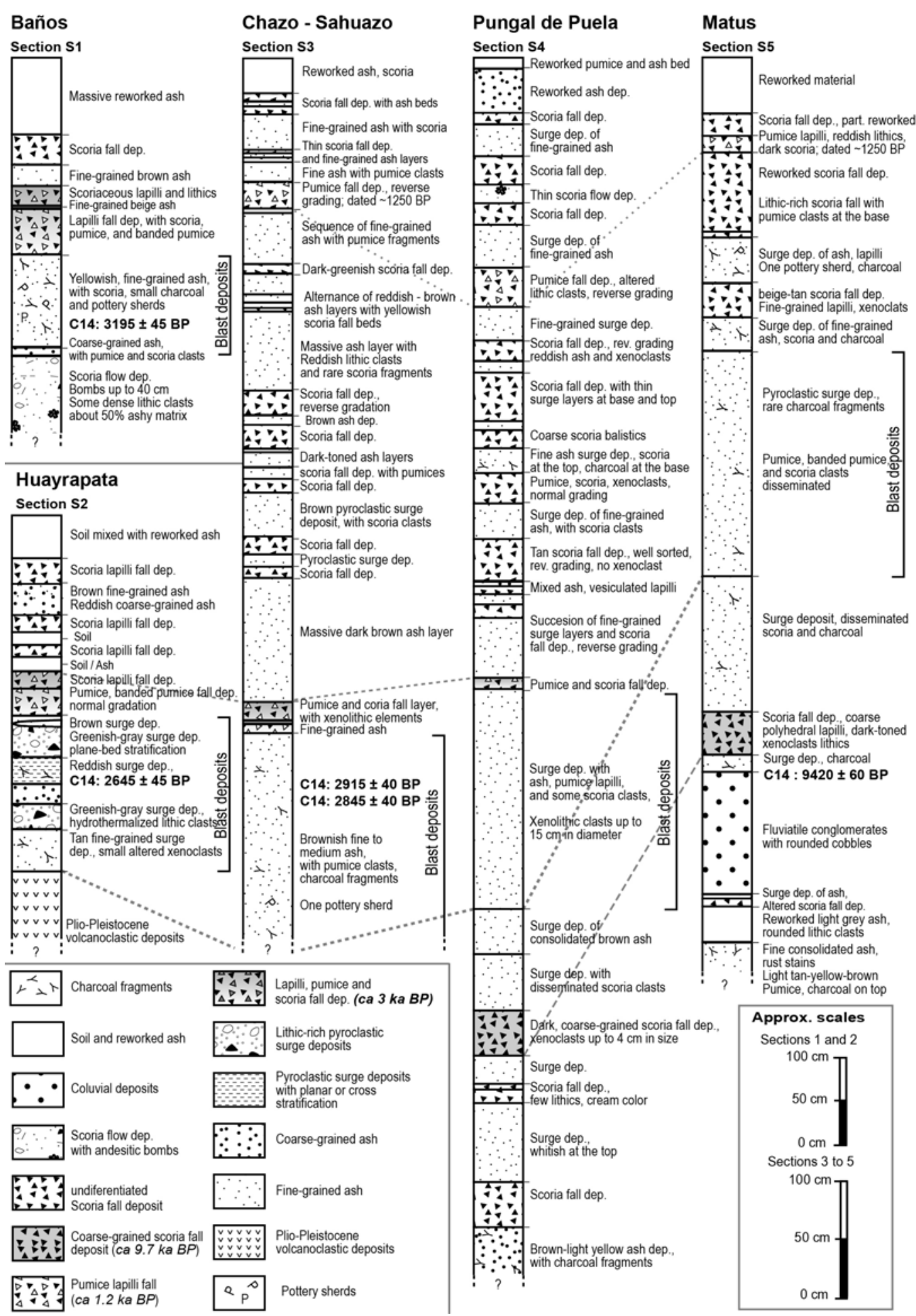

Figure 3 Selected sections showing tephra stratigraphy around Tungurahua Volcano, with emphasis on the main $\sim 1100$ cal BC pyroclastic layers. Section numbers refer to the sites noted from S1 to S5 in Figure 2 (dep. = deposit). 


\section{J-L Le Pennec et al.}

ria fall layer, as notable erosion took place at the surface of the avalanche breccia before deposition of the younger scoria fall deposit, indicating a significant time interval between both events. This is supported by a ${ }^{14} \mathrm{C}$ determination of 30,690 $\pm 180 \mathrm{BP}$ (GrA-28557) obtained on small charcoal fragments at the base of a debris avalanche deposit exposed near the bridge of Las Juntas, a location where the Chambo and Patate rivers join together to form the Pastaza River (Figure 2).

\section{Age of the Major Explosive Volcanic Event}

${ }^{14} \mathrm{C}$ results for these remarkable deposits range from $2640 \pm 45$ to $3195 \pm 45 \mathrm{BP}$, with 3 outliers at $2225 \pm 35,2255 \pm 30$, and $5195 \pm 45$ BP. However, the volcanological evidence unambiguously indicates that the deposits were emplaced in a very short time interval, within several hours of strong explosive activity (see below for a comparison with the 1980 Mount St. Helens eruption). We therefore surmise that possibly old-wood effects and old or young carbon contaminations may account for some scatter in these data. We converted the ${ }^{14} \mathrm{C}$ results to calendar ages using the CALIB v 6 software (Stuiver and Reimer 1993). Tungurahua occurs in an equatorial environment under the influence of air masses from both Northern and Southern hemispheres. It is therefore unclear whether the Northern or Southern calibration curve is appropriate for conversion purposes. Test calibration analyses with both curves indicate that the offset is not significant, about a few decades in most cases. In this study, we selected the IntCal09 curve (Reimer et al. 2009), as it rely on a large data set, but to account for these interhemispheric uncertainties we report the calibrated results by rounding to $5 \mathrm{yr}$ for each determination at $1 \sigma$ and $2 \sigma$ confidence levels (Table 1 ).

Discarding the 3 outliers, we calculate a weighted average ${ }^{14} \mathrm{C}$ age of $2935 \pm 16$ BP for the remaining 7 determinations, which convert to calibrated age ranges of $1210-1115 \mathrm{cal} \mathrm{BC}$ at $1 \sigma$ confidence level and 1255-1240 (3\% relative area) and 1215-1055 cal BC (97\% relative area) at $2 \sigma$. Without further elements to refine this age determination, we consider here that the event took place roughly between 1250 and $1050 \mathrm{cal} \mathrm{BC}$, and most likely between 1220 and $1050 \mathrm{cal} \mathrm{BC}$, and the expression “ 1100 cal BC” used throughout this paper refers to this extended time interval.

\section{Petrologic Characterization of the $\sim 1100$ cal BC Tephra}

The magmatic (juvenile) elements within the $\sim 1100$ cal BC lapilli deposits essentially occur as whitish pumice and dark-toned to brownish scoria clasts. Some lapilli fragments display both textures within a single clast, suggesting a mixture of 2 magmas with different compositions. Chemical analyses of the juvenile material support this interpretation, as 2 contrasting compositions are revealed (Table 2). Gray scoria samples are vesicular and porphyritic andesites (57-58 wt $\% \mathrm{SiO}_{2}$ ) bearing a mineral assemblage of plagioclase, orthopyroxene, clinopyroxene, and Fe-Ti oxides, with scarce olivine phenocryst, and a ground mass texturally ranging from glassy to intersertal. In contrast, the white pumice samples are dacitic in composition (63-64 wt\% $\mathrm{SiO}_{2}$ ), with a mineral assemblage similar to that of the andesitic counterparts, but olivine is absent. Under the binocular microscope, these pumice samples show a glassy texture with abundant elongated vesicles and scarce phenocrysts.

Both compositions occur in the overall compositional trend of Tungurahua samples (Figure 4). The andesitic scoria displays the archetypical geochemical and mineralogical compositions of Tungurahua magmas (Hall et al. 1999; Samaniego et al. 2011), whereas the dacitic pumice has a composition similar to that of other silica-rich Tungurahua magmas (such as those of the $1250 \mathrm{BP}$ and AD 1886 and 2006 eruptions). However, the 1100 cal BC samples have slightly higher incompatible trace elements contents (e.g. $\mathrm{K}_{2} \mathrm{O}, \mathrm{Rb}, \mathrm{Ba}$, Th) and most importantly do not bear amphibole

phenocryst. The absence of this mineral is useful to pinpoint the $1100 \mathrm{cal} \mathrm{BC}$ tephra among other silicic tephras from Tungurahua, and to correlate the layer on a regional scale in central Ecuador. 
Plinian Eruption at Tungurahua Reveals Formative Occupation

Table 2 Results of chemical analyses for pumice and scoria samples collected in the main lapilli fall layer near Baños cemetery (TU.BA samples A and B) and near the viewpoint (Mirador) of the Runtún Plateau (TU.MR. samples A to D). Major and trace elements obtained by ICP-AES at Université de Bretagne Occidentale (Brest, France), by J Cotten.

\begin{tabular}{|c|c|c|c|c|c|c|}
\hline Sample nr: & TU.BA.A & TU.BA.B & TU.MR.A & TU.MR.B & TU.MR.C & TU.MR.D \\
\hline Locality: & Baños & Baños & Runtún & Runtún & Runtún & Runtún \\
\hline Nature: & Gray scoria & White pumice & Gray scoria & White pumice & Gray scoria & White pumice \\
\hline Composition: & andesite & dacite & andesite & dacite & andesite & dacite \\
\hline \multicolumn{7}{|l|}{$(\mathrm{wt} \%)$} \\
\hline $\mathrm{SiO}_{2}$ & 57.40 & 62.70 & 57.15 & 62.10 & 57.30 & 63.00 \\
\hline $\mathrm{TiO}_{2}$ & 0.89 & 0.64 & 0.88 & 0.68 & 0.88 & 0.65 \\
\hline $\mathrm{Al}_{2} \mathrm{O}_{3}$ & 16.55 & 15.45 & 16.60 & 15.65 & 16.36 & 15.15 \\
\hline $\mathrm{Fe}_{2} \mathrm{O}_{3}{ }^{\mathrm{a}}$ & 7.42 & 4.99 & 7.40 & 5.33 & 7.40 & 5.24 \\
\hline $\mathrm{MnO}$ & 0.11 & 0.08 & 0.12 & 0.09 & 0.12 & 0.09 \\
\hline MgO & 4.52 & 2.30 & 4.52 & 2.46 & 4.56 & 2.43 \\
\hline $\mathrm{CaO}$ & 6.60 & 4.45 & 6.75 & 4.67 & 6.68 & 4.50 \\
\hline $\mathrm{Na}_{2} \mathrm{O}$ & 3.90 & 3.90 & 3.76 & 3.74 & 3.88 & 3.78 \\
\hline $\mathrm{K}_{2} \mathrm{O}$ & 1.75 & 2.68 & 1.68 & 2.50 & 1.73 & 2.68 \\
\hline $\mathrm{P}_{2} \mathrm{O}_{5}$ & 0.25 & 0.21 & 0.25 & 0.22 & 0.25 & 0.21 \\
\hline LOI & 0.41 & 2.01 & 0.74 & 2.39 & 0.25 & 1.90 \\
\hline Total & 99.80 & 99.41 & 99.85 & 99.83 & 99.41 & 99.63 \\
\hline \multicolumn{7}{|l|}{ (ppm) } \\
\hline Sc & 17 & 9.8 & 17.5 & 11 & 17 & 10.5 \\
\hline V & 175 & 107 & 176 & 115 & 175 & 112 \\
\hline $\mathrm{Cr}$ & 145 & 55 & 148 & 68 & 145 & 64 \\
\hline Co & 26 & 14 & 26 & 14.5 & 26 & 15 \\
\hline $\mathrm{Ni}$ & 63 & 24 & 61 & 27 & 62 & 24 \\
\hline $\mathrm{Rb}$ & 45 & 82 & 44 & 78 & 44.5 & 84 \\
\hline $\mathrm{Sr}$ & 586 & 456 & 580 & 461 & 585 & 439 \\
\hline $\mathrm{Y}$ & 17 & 18.0 & 17.2 & 19.2 & 17 & 18.8 \\
\hline $\mathrm{Zr}$ & 148 & 199 & 146 & 204 & 144 & 200 \\
\hline $\mathrm{Nb}$ & 6.3 & 8.0 & 6.6 & 8.0 & 6.3 & 7.6 \\
\hline $\mathrm{Ba}$ & 800 & 1130 & 800 & 1135 & 800 & 1150 \\
\hline $\mathrm{La}$ & 18.8 & 24.3 & 18.4 & 24.4 & 18.2 & 24.6 \\
\hline $\mathrm{Ce}$ & 37 & 47.5 & 38.5 & 49 & 36 & 47 \\
\hline Nd & 20 & 23 & 19.5 & 23 & 19.6 & 23.5 \\
\hline $\mathrm{Sm}$ & 4.2 & 4.4 & 4.2 & 4.6 & 4.1 & 4.6 \\
\hline $\mathrm{Eu}$ & 1.1 & 1.0 & 1.1 & 1.1 & 1.1 & 1.0 \\
\hline Gd & 3.6 & 4.0 & 3.9 & 4.3 & 3.6 & 4.0 \\
\hline Dy & 3.1 & 3.1 & 3.2 & 3.4 & 3.0 & 3.2 \\
\hline $\mathrm{Er}$ & 1.7 & 1.7 & 1.7 & 1.8 & 1.7 & 1.8 \\
\hline $\mathrm{Yb}$ & 1.5 & 1.6 & 1.5 & 1.7 & 1.6 & 1.6 \\
\hline Th & 6.1 & 11.5 & 6.3 & 11.5 & 6.2 & 11.4 \\
\hline
\end{tabular}

${ }^{\mathrm{a}} \mathrm{All} \mathrm{Fe}$ as $\mathrm{Fe}_{2} \mathrm{O}_{3}$.

\section{Description and Size of the $\sim \mathbf{1 1 0 0}$ cal BC Eruption}

The distribution, thickness, grain size, and textural characteristics of the deposits and chemical compositions of the juvenile clasts provide clear evidence that these tephra originate from a major explosive event of Tungurahua. Stratigraphic association of the massive ash strata and the lapilli fall layers with a debris avalanche breccia (e.g. Mandur ravine, Chacauco scarp, and Pillate cliff, Figure 2) indicates that the deposits belong to a single volcanic event, most likely similar to that of Mount St. Helens, USA, in May 1980 (Lipman and Mullineaux 1981). The sector collapse and subsequent avalanche event at Tungurahua were probably triggered by flank deformation and destabilization 


\section{$J-L$ Le Pennec et al.}

induced by magma intrusion inside the volcano. Sudden decompression of the magma when flank collapse took place resulted in a violent, high-velocity directed blast explosion, which spread rapidly over the rugged topography around the volcano and deposited the charcoal- and sherd-rich ash layers. The area within the envelope of present-day outcrops where the blast deposit is exposed is $\sim 600 \mathrm{~km}^{2}$, corresponding to a minimum blast layer volume of $0.85 \mathrm{~km}^{3}$ (Jaya 2003). Concomitantly, a vertical eruptive column rose high above the crater, and a rain of lapilli showered the area with pumice and scoria fragments. Using an isopach map of the deposit (Figure 3) and a calculation model (Fierstein and Nathenson 1992), we estimate the bulk volume of the lapilli fall layer at $\sim 0.45 \mathrm{~km}^{3}$. On the Volcanic Explosivity Index (VEI) scale, the overall size of the eruption is thus ranked at 5, a magnitude similar to that of the 1980 Mount St. Helens event. Ongoing geological work reveals that this eruption is the most powerful in the past $9000 \mathrm{yr}$ of activity at Tungurahua, i.e. 2 orders of magnitude higher than the violent August 2006 eruption (Eychenne et al. 2012, 2013).

According to our volcanological data, the tall eruptive tephra column ( $20-25 \mathrm{~km}$ high) fed a volcanic cloud that initially drifted to the north of the volcano, and later to the west and southwest (Jaya 2003). This is consistent with the lack of tephra layers around $3 \mathrm{ka}$ BP in core sediments from Holocene glacial lakes of southern Ecuador (Rodbell et al. 2002). On the other hand, the eruptive cloud very likely floated to the west above areas between the Quilotoa and Chimborazo volcanoes (indexed 15 and 17, respectively, in Figure 1) and possibly deposited some ash on the archaeological sites of Quevedo-La Maná, where tephra layers of similar age have been ${ }^{14} \mathrm{C}$ dated by GuillaumeGentil (2008). Particularly, his tephra layers V (1130-830 cal BC, $2 \sigma$ ) and VI (1450-1110 cal BC, $2 \sigma)$ are good candidates for correlation to our 1250-1050 cal BC deposits from Tungurahua, but imprecise tephra description at Quevedo-La Maná sites hampers refining the correlation.

\section{ARCHAEOLOGICAL INVESTIGATIONS}

\section{Sampling and Method}

The hot, high-velocity pyroclastic density current (blast) spread over an uneven topography and incorporated the ceramics, which most likely fragmented later during transport into numerous pieces. Therefore, the sites where we collected the sherds in the blast deposit are presumably located at some distance from their original site. Similar situations are well known in the town of Pompeii, Italy, which was destroyed during the famous AD 79 eruption of Mount Vesuvius (Gurioli et al. 2005). We gathered 38 sherds from Baños cemetery (22 pieces) and the Runtún Plateau (15 pieces from 2 sublocalities separated by $\sim 8 \mathrm{~m}$ ), both being located on the north side of the volcano, and from a hill north of El Chazo village (1 piece), southwest of the edifice (Figures 2 and 3). On the southern flank of Igualata Volcano, west of Cullog village, we collected 1 sherd at the base of a seemingly old, subconsolidated, and fractured debris flow deposit. The latter rests directly upon an older debris flow deposit, whose ashy top-layer contains small charcoal fragments. The charcoal debris are dated to $3635 \pm 40 \mathrm{BP}$ (GrA-34161, Table 1) and we thus consider that the sherd in the above debris flow deposit is likely subcontemporaneous with those of the Baños, Runtún, and Chazo areas. This sherd is not considered in the description below, but it suggests that the whole region already hosted many settlements around $3 \mathrm{ka} \mathrm{BP}$.

The selected sherds from Baños, Runtún, and Chazo show a diversity of size, shape, color, and ornamentation. Examination of the pastes, surface finish, and firing indicates that this material shares many common features from site to site. While most sherds are too small or archaeologically inconclusive in terms of cultural origin, others display diagnostic features of a specific cultural period. We summarize below the main types of pastes and shapes of the recipients, and compare with previously documented archaeological material of the Formative cultural period of Ecuador. 

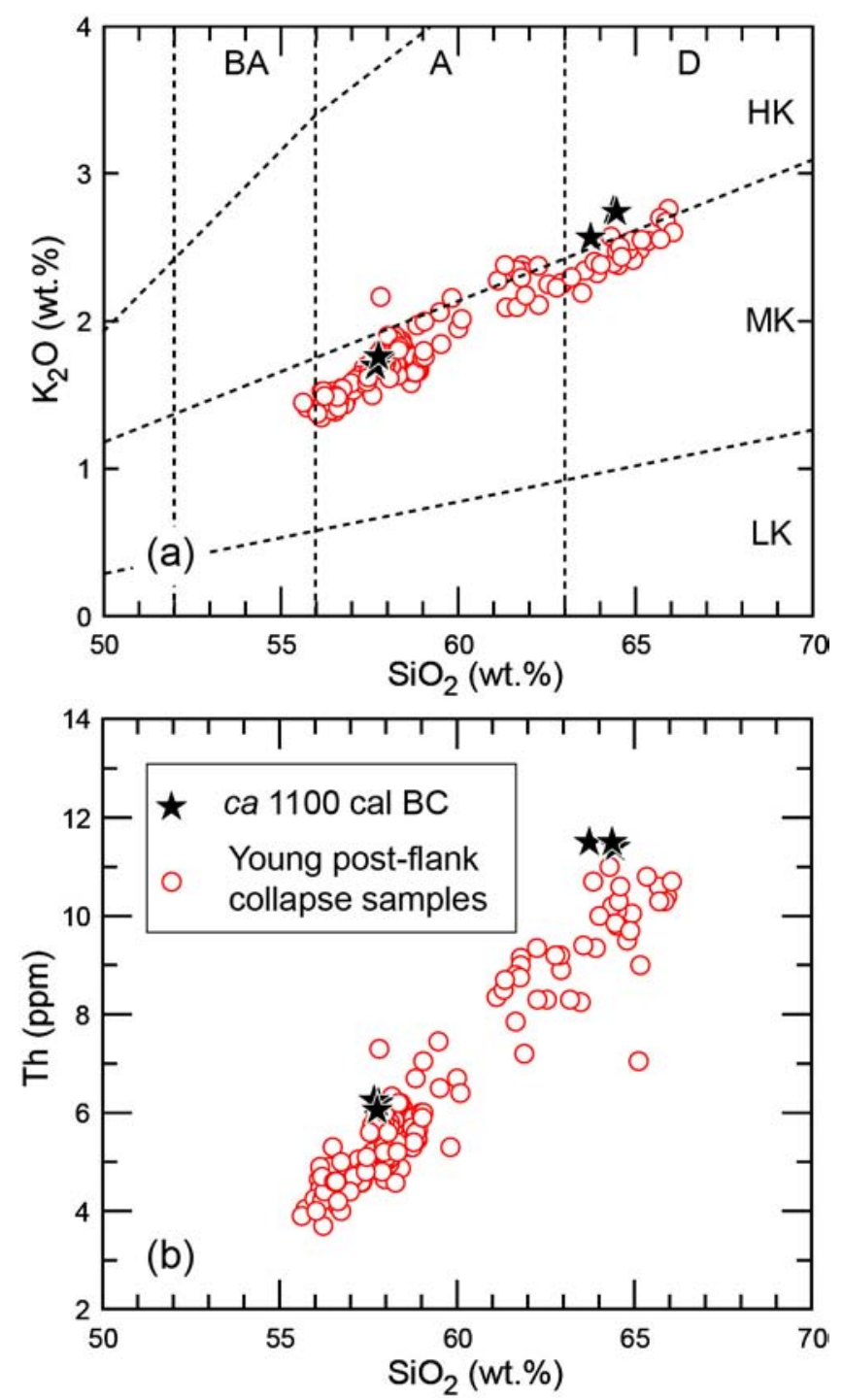

Figure $4 \mathrm{~K}_{2} \mathrm{O}$ (a) and $\mathrm{Th}$ (b) data plotted against $\mathrm{SiO}_{2}$ for $\sim 1100$ cal BC lapilli samples (solid stars) as well as post-sector collapse undifferentiated samples (open symbols). The fields in the $\mathrm{SiO}_{2}$ vs. $\mathrm{K}_{2} \mathrm{O}$ classification diagram are modified from Peccerillo and Taylor (1976). BA, basic andesite; A, andesite; D, dacite; LK, low potassium; MK, medium potassium; HK, high potassium.

\section{Description of the Material}

The size of the sherd ranges from 2.5 to $7 \mathrm{~cm}$, with a thickness typically between $\sim 0.3$ and $0.8 \mathrm{~cm}$. Three different types of paste are distinguished: Paste 1: In the collection, 25 sherds show a temper with a few minerals about $1 \mathrm{~mm}$ in maximum length; shining black crystals are likely amphiboles (and minor pyroxene?), while matt whitish to yellowish elements are plagioclase crystals. Rare elongate cavities, $\sim 1 \mathrm{~mm}$ in length, occur within the paste. The sherd surfaces show complete and incomplete firing. The colors range from orange to brown to dark- to light-gray. An analysis of the 


\section{J-L Le Pennec et al.}

shapes suggests that most potsherds belong to globular recipients with necks, as evidenced by an everted rim from a jar fragment (Figure 5, sherd 4). Some sherds have decorations with a burnish line (Figure 5, sherds 3 and 7), in some cases with slip (red, orange, and beige tones are present; Figure 5, sherd 6), and 1 sherd shows an orange slip with punctuates 1-2 mm in diameter (Figure 5, sherd 5). The only open shape in our collection is from a carinated bowl, with an aperture of $18 \mathrm{~cm}$ in diameter and circular punctuates about 2-3 mm in size (Figure 5, sherd 1). Paste 2: Eleven sherds have the same temper as above, but the paste is finer-grained and large particles are fewer. The paste, is $\sim 0.5 \mathrm{~cm}$ thick and hosts scarce cavities. The firing is incomplete in most cases, and colors include orange, reddish, and brown tones. All potsherds exhibit a smoothed external finish. One sherd shows a delicate decoration with burnish lines on parallel superficial incisions (Figure 5, sherd 2). Paste 3: Two sherds include this type of paste. One of them is thin $(0.35 \mathrm{~cm})$ and displays a very fine-grained, homogeneous, and compacted paste in which temper's grains are difficult to distinguish under the naked eye. The firing is incomplete, the color is dark gray, and the surface has undergone smoothing. None of these sherds is diagnostic. Overall, in spite of the high degree of fragmentation due to multiple collisions in the hot volcanic density current, the material is homogeneous and essentially consists of pieces of jars with necks, with oval to subspherical bodies (Figure 5).

\section{Comparison with Contemporaneous Material and Discussion}

The material from Tungurahua shows marked affinities with the Cotocollao tradition, which developed in Quito's region between 1500 and 500 BC (Villalba 1988:245): a) The use of burnished lines (Figure 5, sherds 2, 3, and 7) and circular punctuates are common in the Cotocollao tradition on bowls and jars (Figure 5, sherd 5), notably from those of the first phase, Ia, between 1500 and 1300 BC (Villalba 1988:226); b) The everted rim from a jar (Figure 5, sherd 4) is similar to the formal class XXVII described in Villalba's classification, which appeared in the Quito area in period Ib, at 1300-1100 BC (Villalba 1988:206-7); c) The only open recipient, a carinated bowl with circular punctuates (Figure 5, sherd 1), displays features related to the formal class VIII, which is one of the most typical form and decorative patterns of this tradition, from the period IIb, around 800500 BC (Villalba 1988:154-6). However, we wonder if the bowl from the Tungurahua region has an annular base, as is typical in Cotocollao tradition. Additional comparisons with other traditions can be proposed. Apart from traditions of the Formative period, only 1 culture shows this type of decorated recipient. The Machalilla tradition, known since the 1960s on the Ecuadorian coast, shows the occurrence of carinated bowls with punctuate decoration around 1500-1000 BC, with the "Machalilla Embellished Shoulder” type (Meggers et al. 1965:124-6).

In spite of the convincing resemblances, the main limitation of the correlation to Cotocollao lies in the fact that our comparisons are not chronologically homogeneous, as they vary between phases Ia, $\mathrm{Ib}$, and IIb of the Cotocollao tradition, which is considered as a possible source of stylistic Formative features in the whole Quito area. This concern may result from the high degree of fragmentation of the ceramics, and the resulting small size of our samples. Conversely, a comparison with the shorter Machalilla tradition suggests a different explanation because of the earlier appearance of carinated bowls with punctuation in this tradition. We propose that a coastal influence came earlier at the foothill of the Tungurahua region, and later reached Cotocollao.

The hypothesis of an Amazonian cultural influence is another option to explain the above chronostylistic discrepancy. In fact, it is worth noting that the Pastaza archaeology is very poorly known from previous studies. Recent field investigations in the Puyo area, 30 km east of Tungurahua Volcano (Figure 1), unearthed a ceramic tradition with carinated forms and decoration with punctuations (Rostain 2012). We speculate that the Amazonian tradition could have attained the Tungurahua 

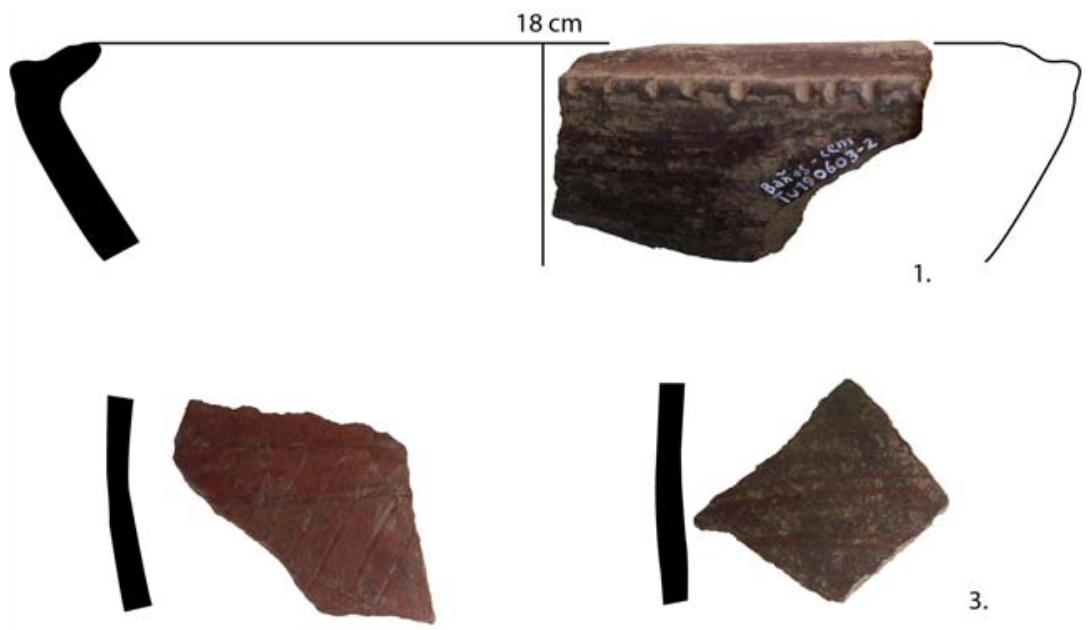

2.
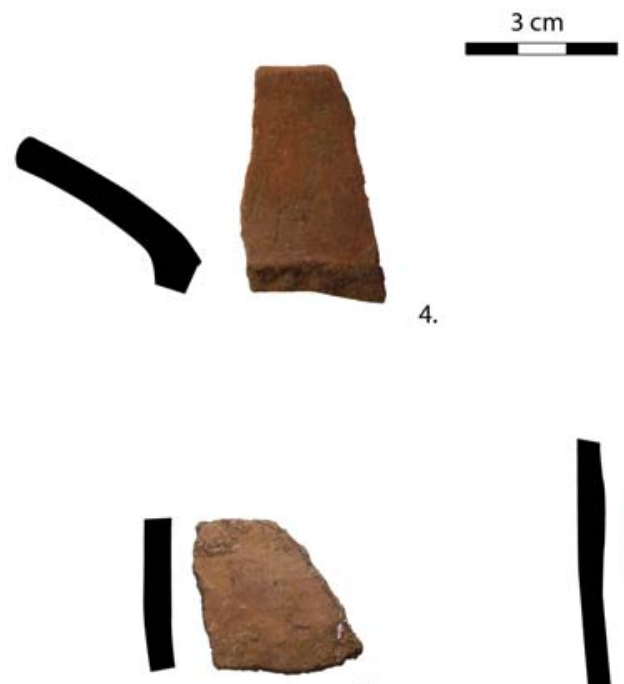

6.

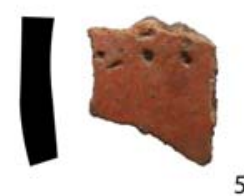

5.

Figure 5 Selected illustrations of diagnostic material identified in our sample collection from Tungurahua Volcano. Sherd 1: Rim of a carinated bowl with circular punctuates, collected north of Baños cemetery. This type of vessel is typical of the Formative Cotocollao tradition in a posterior period. Sherd 2: Potsherd with superficial incisions and 2 burnished lines, collected north of Baños cemetery. Sherd 3: Potsherd with burnished lines, north of Baños cemetery. Sherd 4: Everted rim from a jar, site 1 near the viewpoint (Mirador) of Runtún Plateau. Sherd 5: Sherd with orange slip and punctuated decorations, site 2 near the Mirador of Runtún Plateau. Sherd 6: Sherd with beige slip, site 2 near the viewpoint (Mirador) of Runtún Plateau. Sherd 7: Sherd from a firepot body. The burnished lines are visible, collected on a site near the road from Chazo to Sahuazo (see Figure 2 for location).

area and a pre-Cotocollao influence (or interaction) from Pastaza may have reached the Tungurahua region during the Formative period.

The Tungurahua edifice dominates the Pastaza Valley (Figure 2), which is 1 of the 3 major Ecuadorian routes to the Amazonian lowlands. The valley likely promoted pre-Columbian interactions 


\section{J-L Le Pennec et al.}

between the regions, especially for Spondylus trade (Valdez et al. 2005). Our findings suggest that the Tungurahua region was a part of a simultaneous cultural interaction sphere within northern (Quito), western (Pacific coast), and maybe eastern (Amazonia) influences, although the links with southern Andean cultures are not clear yet. In contrast, the Formative traditions known from collections and excavations in Alausí, Cerro Narrío, and Challuabamba (Porras 1977; Collier and Murra 2007; Grieder et al. 2009) show little affinity with those described in this study.

Discovery of the Tungurahua material allows us to assert that the ceramic remains are part of a stylistic tradition that lasted for centuries in the Andean and Amazonian regions. Bolivian archaeologist J Arellano (1994, 1997, 1999) described a material from a site called Loma Pucará in the Cebada Valley, $25 \mathrm{~km}$ south of Riobamba city (Figure 1), with Late Formative material ${ }^{14} \mathrm{C}$ dated from 2600 to $2300 \mathrm{BP}$. Some potsherds display stylistic features that strongly recall the tradition evidenced in our material from the Tungurahua region: this includes carinated forms (especially a shallow bowl with decoration on the shoulder); decoration with punctuations; and globular jars with everted rims (Arellano 1997:88, Figure 15). In addition, a younger ceramic tradition from the Amazonian region exhibits features that are possibly inherited from the Formative material of the Tungurahua area. In ceramic remains from the Puyo region (Figure 1), Valdez and Guffroy (2009) documented samples of possible Late Regional Development age (questions are raised on the reliability of the single ${ }^{14} \mathrm{C}$ determination provided by these authors) with punctuated rims and decorations, and carinated forms with a more complicated geometry. Overall, these similarities suggest possible Amazonian influences throughout the area and indicate that the Amazonian data in general need a closer appraisal.

The 3 ka BP eruption was particularly strong and we suspect that it had a significant and long-lasting impact on human occupation in the area, probably for years to decades. Although indisputable evidence is lacking, we surmise, as for younger major eruptions in the Ecuadorian Andes, that the 3 ka BP event at Tungurahua forced local or regional migrations of populations, and possibly altered some cultural traits. A similar situation is proposed to explain an apparent abandonment of the Upano culture in the area $30 \mathrm{~km}$ east of Sangay Volcano (Figure 1) around AD 400-600, followed by the occurrence a few centuries later of a comparable ceramic material more to the south in the Ucayali River valley, eastern Peru (Rostain 2012:37). Similarly, the impact of Late Holocene volcanic tephra on Andean communities has been discussed for the Chile-Argentina region (Villarosa et al. 2006). However, this work provides evidence that the $3 \mathrm{ka}$ BP volcanic deposits and the associated ceramics result from the earliest volcanic catastrophe documented so far in the Andes.

\section{CONCLUSION}

Our study provides the first evidence of human occupation in the Formative cultural period in a region where very little archaeological data were available from previous research. The age of the occupation is reliably constrained from $7{ }^{14} \mathrm{C}$ age determinations around $1100 \mathrm{cal} \mathrm{BC}$. The material essentially comprises necked jars and a carinated bowl. Some shapes and decorations upon the sherds share affinities with the Cotocollao material described by Villalba (1988) and dated between 1500 and 500 BC, and with Machalilla in the Ecuadorian coastal region (Meggers et al. 1965), dated around 1500-1000 BC. On the other hand, it may be a part of an Upper Amazon tradition, whose age and archaeological characteristics require a refined definition.

The highly fragmented nature of the ceramics and the widespread distribution of the preserved blast deposits strongly suggest that the eruption destroyed different settlements, and likely claimed lives upon and around the volcano. To some extent, these potsherds argue for an old Andean Pompeii and Tungurahua stands for an andesitic Vesuvius. Our study provides evidence that the $\sim 1100 \mathrm{cal} \mathrm{BC}$ 


\section{Plinian Eruption at Tungurahua Reveals Formative Occupation}

Plinian eruptive event at Tungurahua Volcano is among the oldest known volcanic disasters in the Andes, and emphasizes the strongly explosive and hazardous behavior of the presently active edifice. Ongoing research in the Amazonian foothill combined with additional volcanological investigations offer promising ways to better understand the different cultural influences during the Formative period in central and eastern Ecuador.

\section{ACKOWLEDGMENTS}

We conducted this research in the context of scientific French-Ecuadorian cooperation programs. Financial support for fieldwork and laboratory analyses has been provided by IRD, IG-EPN, European Community (ECHO) project "Communities Affected by Tungurahua: Mitigating the Risks of Living Near an Active Volcano," and the Laboratoire Mixte International of IRD "Séismes et Volcans dans les Andes du Nord.” We thank the 2 anonymous reviewers for pointing out relevant references. We dedicate this note to the memory of Dr Jean-Philippe Eissen, who provided help on various aspects of this work. This is Laboratory of Excellence ClerVolc contribution number 51.

\section{REFERENCES}

Arellano J. 1994. Loma Pucará, a Formative site in Cebadas valley, Ecuador. National Geographic Research \& Exploration 10(1):118-20.

Arellano J. 1997. Loma Pucará. Un asentamiento del Formativo tardío en el valle de Cebadas, Sierra central del Ecuador. Fronteras de Investigación 1:78-100.

Arellano J. 1999. Primeras evidencias del formativo tardío en la Sierra central del Ecuador. In: LedergerberCrespo P, editor. Formativo Sudamericano: una reevaluación. Quito: Producciones Digitales UPS. p 160-75.

Athens JS. 1999. Volcanism and archaeology in the Northern Highlands of Ecuador. In: Mothes P, editor. Actividad volcánica y pueblos precolombinos en el Ecuador. Quito: Abya-Yala editions. p 157-89.

Collier D, Murra J. 2007. Reconocimiento y Excavaciones en el Austro Ecuatoriano. Cuenca: Casa de la cultura ecuatoriana, núcleo del Azuay.

Eychenne J, Le Pennec J-L, Troncoso L, Gouhier M, Nedelec JM. 2012. Causes and consequences of bimodal grain-size distribution of tephra fall deposited during the August 2006 Tungurahua eruption (Ecuador). Bulletin of Volcanology 74(1):187-205.

Eychenne J, Le Pennec J-L, Ramon P, Yepes H. 2013. Dynamics of explosive paroxysms at open-vent andesitic systems: high-resolution mass distribution analyses of the 2006 Tungurahua fall deposit (Ecuador). Earth and Planetary Science Letters 361:343-55.

Fierstein J, Nathenson M. 1992. Another look at the calculation of fallout tephra volumes. Bulletin of Volcanology 54(2):156-67.

Grieder T, Farmer J, Hill D, Stahl P, Ubelaker D. 2009. Art and Archaeology of Challuabamba, Ecuador. Austin: University of Texas Press.

Guillaume-Gentil N. 2008. Cinq mille ans d'histoire au pied des volcans en Équateur. Terra Archeologica VI. Neuchâtel: SLSA/Infolio. 258 p.
Gurioli L, Teresa Pareschi M, Zanella E, Lanza R, Deluca E, Bisson M. 2005. Interaction of pyroclastic density currents with human settlements: evidence from ancient Pompeii. Geology 33(6):441-4.

Hall ML, Mothes PA. 2008. Volcanic impediments in the progressive development of pre-Columbian civilizations in the Ecuadorian Andes. Journal of Volcanology and Geothermal Research 176(3):344-55.

Hall ML, Robin C, Beate B, Mothes P, Monzier M. 1999. Tungurahua Volcano, Ecuador: structure, eruptive history and hazards. Journal of Volcanology and Geothermal Research 91(1):1-21.

Jaya DM. 2003. Volcanología del evento explosivo mayor del Tungurahua asociado al colapso de flanco en el Holoceno superior [Thesis Memoir (Engineering Geology)]. Quito: Escuela Politécnica Nacional. 141 p.

Le Pennec J-L, Jaya D, Samaniego P, Ramón P, Moreno S, Egred J, van der Plicht J. 2008. The AD 1300-1700 eruptive periods at Tungurahua volcano, Ecuador, revealed by historical narratives, stratigraphy and radiocarbon dating. Journal of Volcanology and Geothermal Research 176(1):70-81.

Lipman PW, Mullineaux DR, editors. 1981. The 1980 Eruptions of Mount St. Helens, Washington. US Geological Survey Professional Paper 1250. Reston: USGS. 844 p.

Lippi R. 1998. Una exploración arqueológica del Pichincha occidental, Ecuador. Quito: Museo Jacinto Jijón y Caamaño.

Meggers B, Evans C, Estrada E. 1965. Early Formative Period of Coastal Ecuador. The Valdivia and Machalilla Phases. Washington, DC: Smithsonian Institution.

Peccerillo P, Taylor SR. 1976. Geochemistry of Eocene calc-alkaline volcanic rocks from the Kastamonu area, northern Turkey. Contribution to Mineralogy and Petrology 58(1):63-81. 


\section{J-L Le Pennec et al.}

Porras P. 1977. Fase Alausí. Revista de la Universidad Católica, año V, $N^{\circ} 17$, Sept. 1977. Quito: Pontifica Universidad Católica del Ecuador. p 89-160.

Reimer PJ, Baillie MGL, Bard E, Bayliss A, Beck JW, Blackwell PG, Bronk Ramsey C, Buck CE, Burr GS, Edwards RL, Friedrich M, Grootes PM, Guilderson TP, Hajdas I, Heaton T, Hogg AG, Hughen KA, Kaiser KF, Kromer B, McCormac FG, Manning SW, Reimer RW, Richards DA, Southon JR, Talamo S, Turney CSM, van der Plicht J, Weyhenmeyer CE. 2009. IntCal09 and Marine09 radiocarbon age calibration curves, 0-50,000 years cal BP. Radiocarbon 51(4): 1111-50.

Rodbell DT, Bagnato S, Nebolini JC, Seltzer GO, Abbott M. 2002. A late Glacial-Holocene tephrochronology for glacial lakes in southern Ecuador. Quaternary Research 57(3):343-54.

Rostain S. 2012. Between Sierra and Selva: landscape transformations in upper Ecuadorian Amazonia. Quaternary International 249:31-42.

Samaniego P, Le Pennec J-L, Robin C, Hidalgo S. 2011. Petrological analysis of the pre-eruptive magmatic process prior to the 2006 explosive eruptions at Tun- gurahua volcano (Ecuador). Journal of Volcanology and Geothermal Research 199(1-2):69-84.

Stuiver M, Reimer PJ. 1993. Extended ${ }^{14} \mathrm{C}$ data base and revised CALIB $3.0{ }^{14} \mathrm{C}$ calibration program. Radiocarbon 35(1):215-30.

Valdez F, Guffroy J. 2009. Reconocimiento arqueológico en el sitio Rincón Amazónico. In: Duche Hidalgo C, Saulieu G. de. 2009. Pastaza Precolombino. p 19-22.

Valdez F, Guffroy J, de Saulieu G, Hurtado J, Yepez A. 2005. Découverte d'un site cérémoniel formatif sur le versant oriental des Andes. Comptes Rendus Palevol $4(4): 369-74$.

Villalba M. 1988. Cotocollao: una aldea formativa del valle de Quito. Miscelánea antropológico ecuatoriano, Serie Monográfica 2. Quito: Museo del Banco Central del Ecuador.

Villarosa G, Outes V, Hajduk A, Crivelli Montero E, Sellés D, Fernàndez M, Crivelli E. 2006. Explosive volcanism during the Holocene in the Upper Limay River Basin: the effects of ashfalls on human societies, Northern Patagonia, Argentina. Quaternary International 158(1):44-57. 